\title{
Influence Factors of Social Media and Gadget Addiction of Adolescent in Indonesia
}

\author{
M. Octaviano Pratama \\ Sekolah Teknik Elektro dan Informatika, \\ Institut Teknologi Bandung \\ Bandung, West Java, 40132, Indonesia \\ tavgreen@students.itb.ac.id \\ Susmini Indriani \\ Sekolah Teknik Elektro dan Informatika, \\ Institut Teknologi Bandung \\ Bandung, West Java, 40132, Indonesia \\ susmini.indriani@students.itb.ac.id
}

\author{
Dwi Harinitha \\ Sekolah Teknik Elektro dan Informatika, \\ Institut Teknologi Bandung \\ Bandung, West Java, 40132, Indonesia \\ owie_dh@students.itb.ac.id \\ Bryan Denov \\ Sekolah Teknik Elektro dan Informatika, \\ Institut Teknologi Bandung \\ Bandung, West Java, 40132, Indonesia \\ bryan_denov@itb.ac.id
}

\author{
Dimitri Mahayana \\ Sekolah Teknik Elektro dan Informatika, \\ Institut Teknologi Bandung \\ Bandung, West Java, 40132, Indonesia \\ dimitri@stei.itb.ac.id
}

\begin{abstract}
Social media user in Indonesia has growth rapidly since its emergence. In 2019, one of largest social media platform, Facebook has 3 billion world wide users and also 130 million users of them come from Indonesia. Moreover, the other social media like Instagram also has

significantly growth with most of users are teenagers. Massive social media usage was caused by more than 100 million active users that use gadget or smartphone to open application like social media. Both of widely social media and gadget usage is not only have positive impact but also negative impact like mental and behavior problem if the user has been addicted. Hence the requirement of knowing influence factors of social media and gadget addiction in Indonesia is required in order to prevent addiction of social media and gadget. In this paper, the influence factors of social media and gadget addiction in Indonesia is investigated using several techniques like data science, partial least square, and structural

equation modelling. The result: Time, Productivity and Relation are the factors of influencing social media and gadget addiction, meanwhile Thought is not the factor of influencing social media and gadget addiction.
\end{abstract}

Keywords: Social media addiction, gadget addiction, data science, partial least square, structural equation modelling

\section{Introduction}

Social media has widely used in worldwide particularly in Indonesia. It can be seen from one of social media platform, Facebook, which Indonesia users occupied the fourth-highest number world wide in 2018 (Millward 2018). Similar with Facebook, other popular social media, Instagram, reach 60 million users in Indonesia. Massive social media usage was caused by more than 100 million active users that 
use gadget or smartphone to open application like social media. Both of widely social media and gadget usage is not only have positive impact but also negative impact like mental and behavior problem (Kempa 2015), and decrease of academic motivation (Prabandari and Yuliati 2016) if the user has been addicted. The last negative impact is seriously become threat for children and adolescent (Ashwini Veronica and Samuel 2016). Hence the requirement of knowing factors of social media and gadget addiction of adolescent in Indonesia is required in order to prevent addiction of social media and gadget. In this works, we conduct a research about influencing factors of social media and gadget addiction particularly in Indonesia. This research contributes to practical issues and theoretical issues. For theoretical issue, we investigate factors of influencing addiction in using social media and gadget whether there is significant correlation among factors to addiction. For practical issues, this research tries to give best practice to stakeholder to prevent social media and gadget addiction. The outline of this paper as follow: (1) introduction, (2) literature study, (3) research methodology, (4) Result, (5) Discussion and (6) Conclusion.

\section{Literature Study}

Based on prior research by Young et al about addiction of internet (Young 2015), there are twenty question or construct that can indicate someone who addicted by internet. Based on twenty questions, we classify to four categories like "time", "relationship", "productivity" and "thought". Time is defined by Sahin et al (2017) as prefer spend much time on the internet including social media and gadget and affect to life dissatisfaction. Based on this definition, indicator Q1, Q2, Q5, and Q6 are categorized as time variable. Relationship is defined by Veronica (Ashwini Veronica and Samuel 2016) as the usage of social media and gadget can be influenced by relationship with friends, hence the user can easily use social media and gadget influenced by influencer. Based on this definition, indicator Q3, Q4, Q13 are categorized as relationship variable. Productivity is defined as the laziness of doing real-life activity as well as waste much time for unimportant things (Prabandari and Yuliati 2016), hence indicator Q7, Q8, Q14 and Q15 are categorized as productivity variable. The last, Thought is defined as confidentially thought, negative thought, and fear thought of real-life. Hence indicator Q9, Q10, Q11, Q12 is categorized as thought variable. The remaining indicator: Q16, Q17, Q18, Q19, Q20 are categorized as social media and gadget addiction. Based on above explanation, Hypothesis is proposed as follow:

H1: Time is positively related with Social Media or Gadget Addiction

H2: Relationship is positively related with Social Media or Gadget Addiction

H3: Productivity is positively related with Social Media or Gadget Addiction

H4: Though is positively related with Social Media or Gadget Addiction

Four of hypothesis is then observed whether is there correlation or not with social media addiction. Propose model of influence factors of social media addiction can be seen as follow:

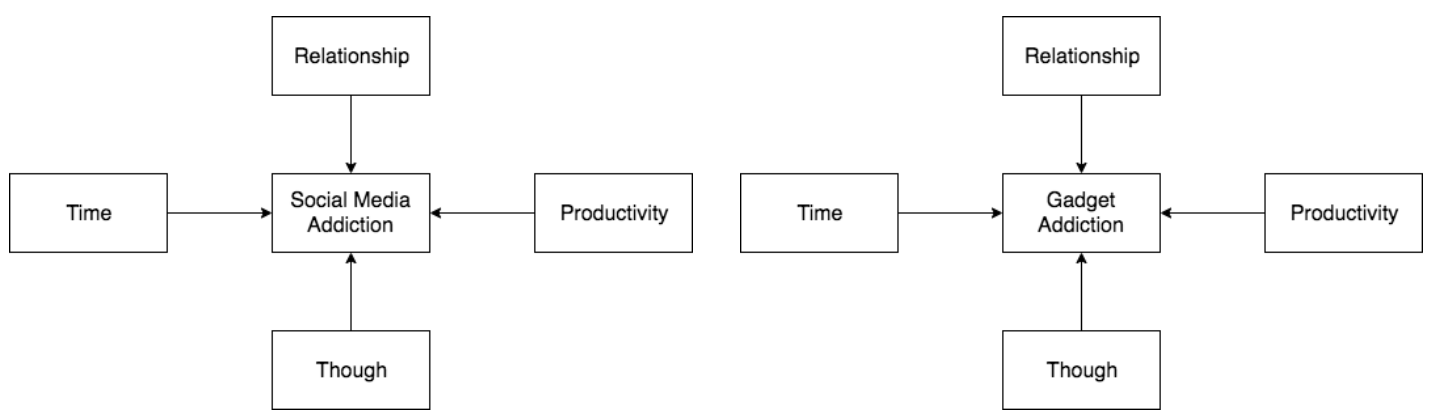

Figure 1. (Left) Influence Factors of Social Media Addiction propose model. The model consists of four factors that will be observed whether is there relationship to social media addiction. (Right) Influence Factors of Gadget Addiction propose model. The model consists of four factors that will be observed whether is there relationship to gadget addiction. 


\section{Research Methodology}

This study is based on quantitative method, which consists of data analysis based on statistical method. Our measurement or construct is derived from prior empirical research: Internet Addiction by Young et al (Young 2015). The construct then modified and adjusted with condition in Indonesia. Final measurement model is in five-point Likert-type scale ranging from "strongly disagree" to "strongly agree". The question is then classified into several categories like "time", "relationship", "productivity" and "thought" based on deeply reading several prior research (Ashwini Veronica and Samuel 2016)(Buran Köse and Doğan 2019)(Şahın 2017). These classes then observed whether is there significantly relationship to social media and gadget addiction. All of construct of measurement is put on online form and spread out to selected audience. In addition, additional information like age, sex, occupation, last education, and city is included in form information.

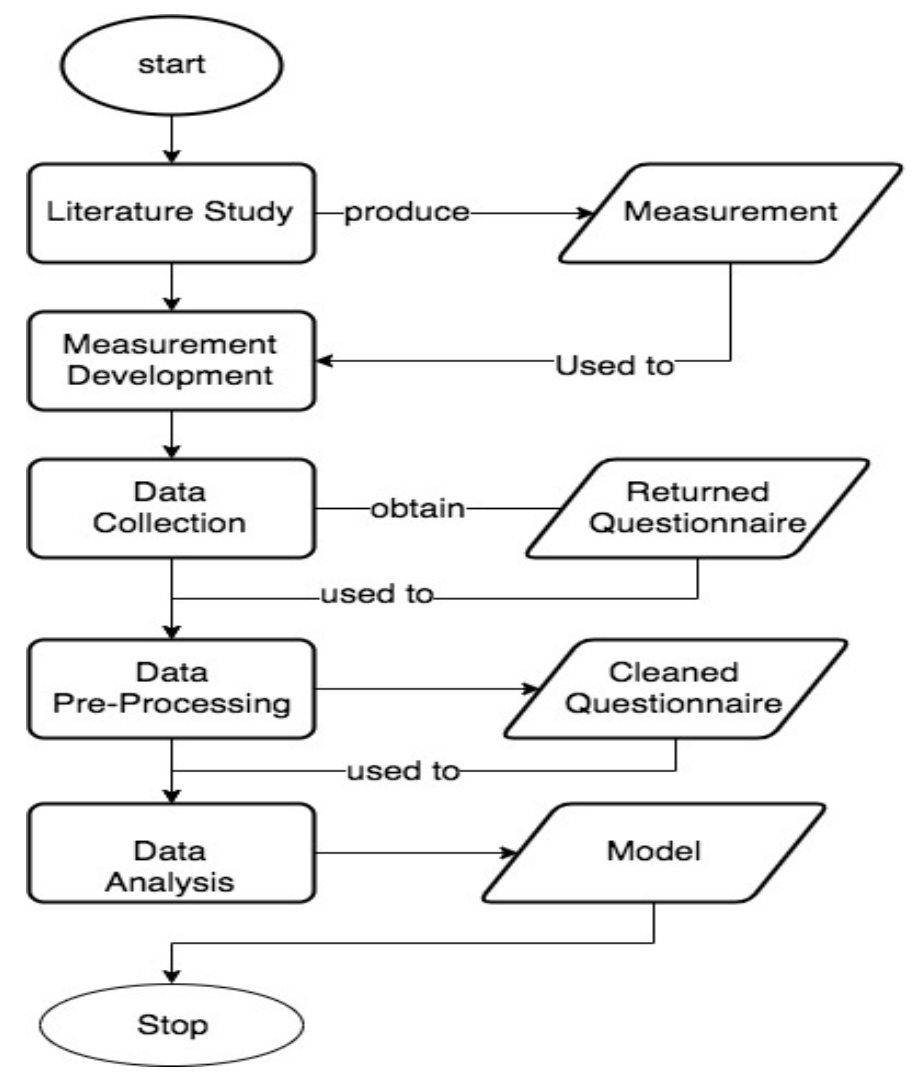

Figure 2. Research Methodology

The first step of research is study literature by reading prior research papers including journal, conference paper, news then measurement or construct is established. Measurement is then modified and adjusted with Indonesia environment. The next step is the measurement spread out to targeted audience then returned questionnaire in data collection. Then returned questionnaire is used in data preprocessing to remove inappropriate data. The last step, cleaning data is used in data analysis to obtain model influence factors of social media and gadget in Indonesia.

Data is collected from respondents who has experience in using social media and gadget. The criteria of respondents are having experience in using social media and gadget, the average of using gadget more than 6 hours per day, and the average of using social media more than 5 hours per day.

After gathering data, the data should be pre-processed in order to obtain cleaned data. We used data science techniques running on Python programming like feature selection (Ng 2004), and tabular preprocessing (Challenge and Scenes 2013) to select appropriate features used in data analysis. 
In this research, combination of Structural Equation Modelling (SEM) (Hox and Bechger 1998) and Partial Least Square (PLS) (Hox 2010) is performed to accept and reject hypothesis. We used several variables output that can determine validity and reliability of model based on prior research (Pratama et al. 2017) like Alpha Cronbach, Correlation, Average Variance Extracted, Discriminant Validity, Consistent Reliability, and others.

In this research, combination of Structural Equation Modelling (SEM) (Hox and Bechger 1998) and Partial Least Square (PLS) (Hox 2010) is performed to accept and reject hypothesis. We used several variables output that can determine validity and reliability of model based on prior research (Pratama et al. 2017) like Alpha Cronbach, Correlation, Average Variance Extracted, discriminant validity, Consistent Reliability, and others.

\section{Result}

\section{Data Collection}

After performing measurement development, we obtained twenty questions complete measurement that can be accessed in appendix A. All of the question is derived from Young et all (Young 2015) strengthened by (Griffiths et al. 2016)(Kurniasanti et al. 2019) then modified based on condition in Indonesia. Based on literature study, the questions are classified into four categories: Time, Relationship, Productivity and Thought.

Table 1. Demography

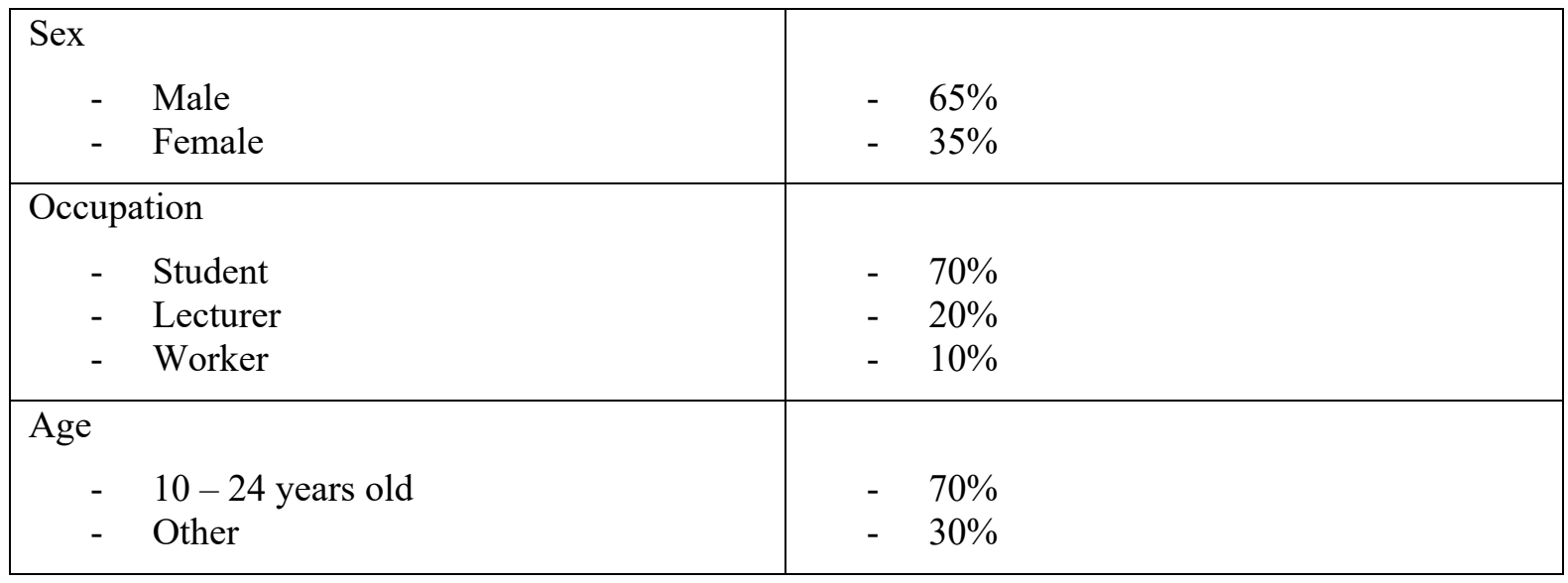

The data was collected in November $11^{\text {th }} 2019$ - November $20^{\text {th }} 2019$ from respondents who have experience in using social media and gadget. We used data science techniques to select appropriate data. From 1782 returned questionnaires, the average of respondent is 27.34 years old with 1089 male and rest are female. Most of respondent are students with 890 audience, the others are lecturer, and workers. Most of students are senior high school student with 713 data. We select merely student occupations for this work. Based on prior research, most of addiction person is dominated from between ages $10-24$ years old and also categorized as adolescent, hence we select only this audience, hence we omit other respondents. We also used L1 feature selection to apply penalty over coefficient that multiply each of predictors. After performing feature selection techniques as well as tabular data pre-processing, we obtained final cleaned questionnaire 385 data. This data is used in analysis.

\section{Social Media Addiction}

First step, we tested the construct whether feasible to be used using outer model analysis. because none of instrument lower than threshold 0.6 , hence none of indicators or instrument should be deleted. We 
measure validity of model using Convergent Validity by utilizing Average Variance Extracted (AVE). Complete AVE score can be seen in Table 2.

Table 2. Loading Factor Social Media Addiction

\begin{tabular}{|c|c|c|c|c|}
\hline Variable & Indicator & $\begin{array}{l}\text { Loading } \\
\text { Factor }\end{array}$ & AVE & CR \\
\hline \multirow[t]{4}{*}{ Time (H1) } & $\overline{\mathrm{Q} 1}$ & 0.622 & \multirow[t]{4}{*}{0.602} & \multirow[t]{4}{*}{0.856} \\
\hline & $\overline{\mathrm{Q} 2}$ & 0.831 & & \\
\hline & Q5 & 0.791 & & \\
\hline & Q6 & 0.839 & & \\
\hline \multirow{3}{*}{$\begin{array}{l}\text { Relationship } \\
\text { (H2) }\end{array}$} & Q3 & 0.877 & \multirow[t]{3}{*}{0.730} & \multirow[t]{3}{*}{0.890} \\
\hline & $\mathrm{Q} 4$ & 0.861 & & \\
\hline & Q13 & 0.824 & & \\
\hline \multirow{4}{*}{$\begin{array}{l}\text { Productivity } \\
\text { (H3) }\end{array}$} & Q7 & 0.555 & \multirow[t]{4}{*}{0.667} & \multirow[t]{4}{*}{0.776} \\
\hline & Q8 & 0.659 & & \\
\hline & Q14 & 0.722 & & \\
\hline & Q15 & 0.778 & & \\
\hline \multirow[t]{4}{*}{ Thought (H4) } & Q9 & 0.758 & \multirow[t]{4}{*}{0.667} & \multirow[t]{4}{*}{0.889} \\
\hline & Q10 & 0.795 & & \\
\hline & Q11 & 0.829 & & \\
\hline & Q12 & 0.880 & & \\
\hline
\end{tabular}

In order to ensure our model is valid, we use additional measurement, discriminant validity and compare AVE square root with each instrument. For example, in Thought AVE square root (0.817) is greater than other, productivity AVE square root is also greater than others. Complete discriminant validity can be seen in Table 3. For ensuring our model reliability, we used two variables: Composite Reliability (CR) and outer loading. All of CR score is greater than threshold 0.7 , hence our model is fulfill internal consistent reliability.

Table 3. Discriminant Validity Social Media Addiction

\begin{tabular}{|l|l|l|l|l|}
\hline & Thought & Productivity & Relationship & Time \\
\hline Though & 0.817 & & & \\
\hline Productivity & 0.630 & 0.684 & & \\
\hline Relationship & 0.742 & 0.654 & 0.855 & \\
\hline Time & 0.632 & 0.563 & 0.662 & 0.776 \\
\hline
\end{tabular}

For the last step, structural test using Structural Equation Modelling is performed to test hypothesis model. Bootstrap is performed to generate random sampling to our construct. Final result can be seen as follow:

Table 4. Bootstrapping Social Media Addiction

\begin{tabular}{|l|l|l|l|l|c|}
\hline Hypothesis & $\begin{array}{l}\text { Path } \\
\text { Coef }\end{array}$ & $\begin{array}{l}\text { Sample } \\
\text { Mean }\end{array}$ & STDEV & t & Sig \\
\hline H1 $\rightarrow$ AMSG & 0.195 & 0.207 & 0.08 & 2.25 & $*$ \\
\hline H2 $\rightarrow$ AMSG & 0.172 & 0.161 & 0.124 & 1.39 & $*$ \\
\hline
\end{tabular}




\begin{tabular}{|l|l|l|l|l|l|}
\hline $\mathrm{H} 3 \rightarrow$ AMSG & 0.475 & 0.488 & 0.093 & 5.114 & $*$ \\
\hline H4 $\rightarrow$ AMSG & $\mathbf{- 0 . 0 9}$ & $\mathbf{- 0 . 0 8}$ & $\mathbf{0 . 1 1 2}$ & $\mathbf{0 . 8 0 5}$ & NS \\
\hline
\end{tabular}

Based on computational using SEM techniques, hypothesis H4 (Thought) is rejected because it did not meet $t>1.972$ with significant level $0.01,0.05$ or 0.1 . Other hypothesis, based on result, factors that influence social media addiction of adolescent in Indonesia are H1 (Time), H2 (Relationship), and H3 (Productivity).

\section{Gadget Addiction}

Similar with social media addiction, the construct is evaluated whether feasible to be used using outer model analysis. because none of instrument lower than threshold 0.6 , hence none of indicators or instrument should be deleted. We measure validity of model using Convergent Validity by utilizing Average Variance Extracted (AVE). For ensuring our model reliability, we used two variables: Composite Reliability (CR) and outer loading. All of CR score is greater than threshold 0.7, hence our model is fulfill internal consistent reliability. Complete AVE score can be seen in Table 5.

Table 5. Loading Factor Gadget Addiction

\begin{tabular}{|c|c|c|c|c|}
\hline Variable & Indicator & $\begin{array}{l}\text { Loading } \\
\text { Factor }\end{array}$ & AVE & $\overline{C R}$ \\
\hline \multirow[t]{4}{*}{ Time (H1) } & $\overline{\mathrm{Q} 1}$ & 0.777 & \multirow[t]{4}{*}{0.642} & \multirow[t]{4}{*}{0.878} \\
\hline & Q2 & 0.831 & & \\
\hline & $\overline{\mathrm{Q} 5}$ & 0.782 & & \\
\hline & Q6 & 0.815 & & \\
\hline \multirow{3}{*}{$\begin{array}{l}\text { Relationship } \\
\text { (H2) }\end{array}$} & Q3 & 0.922 & \multirow[t]{3}{*}{0.780} & \multirow[t]{3}{*}{0.914} \\
\hline & Q4 & 0.892 & & \\
\hline & Q13 & 0.834 & & \\
\hline \multirow{4}{*}{$\begin{array}{l}\text { Productivity } \\
\text { (H3) }\end{array}$} & Q7 & 0.693 & \multirow[t]{4}{*}{0.623} & \multirow[t]{4}{*}{0.814} \\
\hline & Q8 & 0.782 & & \\
\hline & Q14 & 0.666 & & \\
\hline & Q15 & 0.746 & & \\
\hline \multirow[t]{4}{*}{ Though (H4) } & Q9 & 0.666 & \multirow[t]{4}{*}{0.688} & \multirow[t]{4}{*}{0.849} \\
\hline & Q10 & 0.709 & & \\
\hline & $\overline{\text { Q11 }}$ & 0.808 & & \\
\hline & Q12 & 0.867 & & \\
\hline
\end{tabular}

Similar with social media addiction, discriminant validity is also evaluated. Complete discriminant validity can be seen in Table 6 .

Table 6. Discriminant Validity Gadget Addiction

\begin{tabular}{|l|l|l|l|l|}
\hline & Productivity & Relationship & Thought & Time \\
\hline Productivity & 0.702 & & & \\
\hline Relationship & 0.438 & 0.883 & & \\
\hline Thought & 0.469 & 0.722 & 0.767 & \\
\hline Time & 0.566 & 0.549 & 0.609 & 0.802 \\
\hline
\end{tabular}


For the last step, structural test using Structural Equation Modelling is performed to test hypothesis model. Bootstrap is performed to generate random sampling to our construct. Final result can be seen as follow:

Table 7. Bootstrapping Gadget Addiction

\begin{tabular}{|l|l|l|l|l|c|}
\hline Hypothesis & $\begin{array}{l}\text { Path } \\
\text { Coef }\end{array}$ & $\begin{array}{l}\text { Sample } \\
\text { Mean }\end{array}$ & STDEV & t & Sig \\
\hline H1 $\rightarrow$ AMSG & 0.119 & 0.117 & 0.091 & 1.13 & $*$ \\
\hline H2 $\rightarrow$ AMSG & 0.405 & 0.404 & 0.093 & 4.365 & $*$ \\
\hline H3 $\rightarrow$ AMSG & 0.346 & 0.355 & 0.15 & 2.773 & $*$ \\
\hline H4 $\rightarrow$ AMSG & $\mathbf{- 0 . 0 7 8}$ & $\mathbf{- 0 . 0 7 2}$ & $\mathbf{0 . 1 1 1}$ & $\mathbf{0 . 7 0 0}$ & NS \\
\hline
\end{tabular}

Based on computational using SEM techniques, hypothesis H4 (Though) is rejected because it did not meet $t>1.972$ with significant level $0.01,0.05$ or 0.1 . Other hypothesis, based on result, factors that influence gadget addiction of adolescent in Indonesia are H1 (Time), H2 (Relationship), and H3 (Productivity).

\section{Discussion}

From 1782 returned questionnaire, 1397 data is omitted and remaining 385 data because of several reasons: (1) the audience is not fulfilled desire target (age, occupation). We omit occupation like civil servant, workers and others. we merely select student as audience. (2) the audience fill questionnaire multiple time, (3) the audience is not consistent with the answer. This filtering result is produced from L1 feature selection. Based on analysis of data, H4 (Thought) is rejected because is not significantly affected social media and gadget addiction. The reason of rejected as follow: (1) defensive and confidential thought sometimes is not significantly affected to social media and gadget addiction, it could be because someone needs privacy on using his gadget or social media, (2) social media and gadget sometimes did not provide well information, hence the user can think negatively when accessing social media and gadget. H1 (Time) is accepted as factor of influencing social media and gadget addiction because when someone abandoned real-life activity and tend to use more social media and gadget, it can be categorized as addiction, resulting to spend much time in using gadget and social media. H2 (Relationship) is accepted as factor of influencing social media and gadget addiction because sometimes the using of exaggerate social media and gadget in daily activities is influenced by colleagues or friends. H3 (Productivity) is accepted as factor of influencing social media and gadget addiction because sometimes when people unemployed, they tend to use their gadget or social media more than employed people hence resulting to addiction.

\section{Conclusion}

Social Media and Gadget addiction not only have positive impact but also have negative impact like mental or behavior problem, as well as decrease of academic motivation. Hence the requirement of knowing factors of social media and gadget addiction of adolescent in Indonesia is required in order to prevent addiction of social media and gadget. We investigate influencing factors of social media and gadget addiction by constructing Partial Least Square and Structural Equation Modeling. The result, Time, Productivity and Relation are the factors of influencing social media and gadget addiction, meanwhile Thought is not the factor of influencing social media and gadget addiction. 


\section{References}

Ashwini Veronica, S., and Samuel, A. U. 2016. "Social Media Addiction among Adolescents with Special Reference to Facebook Addiction," IOSR Journal Of Humanities And Social Science (December), pp. 2279-837. (www.iosrjournals.org).

Buran Köse, Ö., and Doğan, A. 2019. "The Relationship between Social Media Addiction and SelfEsteem among Turkish University Students," Addicta: The Turkish Journal on Addictions (6:1), pp. 175-190. (https://doi.org/10.15805/addicta.2019.6.1.0036).

Challenge, I. A., and Scenes, A. 2013. "A TONE-FIT FEATURE REPRESENTATION FOR SCENE CLASSIFICATION Johannes D . Krijnders , Gineke A . Ten Holt 9401 HJ Assen The Netherlands," ICASSP, IEEE International Conference on Acoustics, Speech and Signal Processing - Proceedings (324:February 2016), pp. 359-367. (https://doi.org/10.1007/978-81322-2126-5).

Griffiths, M. D., Kuss, D. J., Billieux, J., and Pontes, H. M. 2016. "The Evolution of Internet Addiction: A Global Perspective," Addictive Behaviors (53), pp. 193-195. (https://doi.org/10.1016/j.addbeh.2015.11.001).

Hox, J. 2010. Handbook of Partial Least Squares. (https://doi.org/10.1007/978-3-540-32827-8).

Hox, J., and Bechger, T. 1998. An Introduction to Structural Equation Modeling, pp. 1-17. (http://joophox.net/publist/semfamre.pdf).

Kempa, E. 2015. Social Media Addiction: The Paradox of Visibility \&amp; Vulnerability, (Independen), $\quad$ p. $60 . \quad$ (http://hb.divaportal.org/smash/get/diva2:867437/FULLTEXT01.pdf\%0Ahttp://urn.kb.se/resolve?urn=urn:nbn :se:hb:diva-1030).

Kurniasanti, K. S., Assandi, P., Ismail, R. I., Nasrun, M. W. S., and Wiguna, T. 2019. "Internet Addiction: A New Addiction?," Medical Journal of Indonesia (28:1), pp. 82-91. (https://doi.org/10.13181/mji.v28i1.2752).

Millward, S. 2018. "Indonesia to Be World's Fourth-Largest Smartphone Market by 2018." (https://www.techinasia.com/indonesia-worlds-fourth-largest-smartphone-2018-surpass-100million-users).

Ng, A. 2004. "Feature Selection, L 1 vs. L 2 Regularization, and Rotational Invariance," Twenty-First International Conference on Machine Learning - ICML '04, p. 78. (https://doi.org/10.1145/1015330.1015435).

Prabandari, K., and Yuliati, L. N. 2016. "The Influence of Social Media Use and Parenting Style on Teenagers' Academic Motivation and Academic Achievement," Journal of Child Development Studies (1:01), p. 39. (https://doi.org/10.29244/jcds.1.01.39-53).

Pratama, M. O., Meiyanti, R., Noprisson, H., Ramadhan, A., and Hidayanto, A. N. 2017. "Influencing Factors of Consumer Purchase Intention Based on Social Commerce Paradigm," 2017 International Conference on Advanced Computer Science and Information Systems (ICACSIS), IEEE, pp. 73-80. (https://doi.org/10.1109/ICACSIS.2017.8355015).

Şahın, C. 2017. "The Predictive Level of Social Media Addiction for Life Satisfaction: A Study on University Students," Turkish Online Journal of Educational Technology (2017:December Special Issue INTE), pp. 515-520.

Young, K. 2015. "The Evolution of Internet Addiction," Addictive Behaviors (64). (https://doi.org/10.1016/j.addbeh.2015.05.016). 


\section{Appendix: Measurement}

\begin{tabular}{|c|c|c|}
\hline Code & Item & $\begin{array}{c}\text { Loading } \\
\text { Factor }\end{array}$ \\
\hline $\begin{array}{l}\text { H1 } \\
\text { Q1 } \\
\text { Q2 } \\
\text { Q5 } \\
\text { Q6 }\end{array}$ & $\begin{array}{l}\text { How often did you use gadget or social media? } \\
\text { How often did you abandon daily activity or homeworks? } \\
\text { How often did your friends or collegues protest to you for spending } \\
\text { much time in using social media or gadget? } \\
\text { How often did social media or gadget disturbt your school works }\end{array}$ & 0.78 \\
\hline $\begin{array}{l}\text { H2 } \\
\text { Q3 } \\
\text { Q4 } \\
\text { Q13 }\end{array}$ & $\begin{array}{l}\text { How often did you choose social media or gadget then communicate } \\
\text { with family or collegues? } \\
\text { How often did you build new relationship with other users? } \\
\text { How often did you anger to your collegues if they disturb you to access } \\
\text { social media and gadget }\end{array}$ & 0.81 \\
\hline $\begin{array}{l}\text { H3 } \\
\text { Q7 } \\
\text { Q8 } \\
\text { Q14 } \\
\text { Q15 }\end{array}$ & $\begin{array}{l}\text { How often did you productivity disturbed because of social media or } \\
\text { gadget? } \\
\text { How often did you check social media or gadget before done your tasks? } \\
\text { How often did you sleepless because of social media or gadget? } \\
\text { How often did you think about social media or gadget when you did not } \\
\text { use it? }\end{array}$ & 0.68 \\
\hline $\begin{array}{l}\text { H4 } \\
\text { Q9 } \\
\text { Q10 } \\
\text { Q11 } \\
\text { Q12 }\end{array}$ & $\begin{array}{l}\text { How often did you defensive or confidential when you access social } \\
\text { media or gadget? } \\
\text { How often did you think negatively when you access social media or } \\
\text { gadget? } \\
\text { How often did you refuse something when you access social media or } \\
\text { gadget? } \\
\text { How often did you think without social media or gadget is boring? }\end{array}$ & 0.69 \\
\hline $\begin{array}{l}\text { Addiction } \\
\text { Q16 } \\
\text { Q17 } \\
\text { Q18 } \\
\text { Q19 } \\
\text { Q20 }\end{array}$ & $\begin{array}{l}\text { How often did you find yourself busy in social media or gadget? } \\
\text { How often did you try to reduce your time in using social media or gadget? } \\
\text { How often did you try to hide yourself silent in using social media or } \\
\text { gadget? } \\
\text { How often did you prefer to use social media or gadget then socialize with } \\
\text { person? } \\
\text { How often did you fill presure or nervous without gadget or social media? }\end{array}$ & 0.72 \\
\hline
\end{tabular}

